\title{
Cold-active enzymes in food biotechnology: An updated mini review
}

\author{
Mohammed Kuddus \\ Department of Biochemistry, University of Hail, Hail, Saudi Arabia
}

\section{ARTICLE INFO}

Article history:

Received on: October 21, 2017

Accepted on: January 07, 2018

Available online: April 05, 2018

Key words: Cold-active enzymes,

Food enzymes,

Psychrophiles,

Cold-adaptation,

Biocatalyst

\section{ABSTRACT}

Cold-active enzymes and their anticipated application in various industries including food industry attracted attention of worldwide scientific community. Cold-active enzymes, also known as psychrophilic enzymes, possess high catalytic activity at low and moderate temperatures. Due to low-temperature activity, these enzymes utilize less energy in biochemical reactions and also stabilize fragile compounds in the reaction medium. The source of coldactive enzymes is basically psychrophilic/psychrotrophic microorganisms which are found in cold environments. In comparison to mesophilic and thermophilic enzymes, till date, very few cold-active enzymes are known and least explored so far in the food industry. This review contains latest development and innovation in cold-active enzymes along with their applications in food biotechnology.

\section{INTRODUCTION}

The role of enzymes is well known in the production of foods since ancient times [1]. One of the most common examples is the production of beverages using an industrial enzyme. Nowadays, the finding of novel enzymes for its commercial applications in the food industry is a challenge for the food scientists and biotechnologists. However, biotechnology is emerged as an advance tool for food industries. This technology is providing new products, improving nutritional value, lowering production costs, improving food processing and also deal with waste problems, food safety problems, and packaging issues. In future also this is going to play an important role in food producing and processing industries. Nowadays, production of almost all commercial foods or its ingredients includes enzymes or enzyme-catalyzed reactions. Some common examples of enzymes application include production of alcoholic beverages, fruit juices, syrups, sweeteners, chocolates, infant foods, egg and bakery products, cheese and dairy products, candy, flavor development, and meat tenderization.

Enzymes have many advantages in food production and processing. The leading one is the replacement of old chemical-based technology with eco-friendly enzymes that provide biodegradable products along with environmental care. Moreover, enzyme-catalyzed processes produce less waste products (byproducts) due to the specific action of enzymes in comparison to chemical catalysts. Although plants, animals, and microbes produce most of the food enzymes, the enzymes produced by

*Corresponding Author

Mohammed Kuddus, Department of Biochemistry,

University of Hail, Hail Saudi Arabia.

Email:mkuddus@gmail.com microbial sources are more advantageous than their equivalents from plant and animal sources due to the following reasons: (1) Low production cost, (2) more predictable and controllable enzyme contents of microbes, (3) easy availability of raw materials with constant composition for their cultivation, and (4) microbes comprises less injurious constituents in comparison to plant and animal tissues. In food industries, there are numerous possible applications of cold-active enzymes along with their producing organisms. Some common specific microbial enzymes used in food industries include $\alpha$-amylase, $\beta$-amylase, $\beta$-glucanase, glucose isomerase and oxidase, aminopeptidase, amyloglucosidase, catalase, cellulase, pectinase, xylanase, cyclodextrin, glucanotransferase, transglutaminase, glucoamylase, hemicellulase, invertase, lactase, lipase, and protease [2-6].

Since past few years, it has been recognized that the cold-adapted enzymes along with its producing microorganisms deals vast prospective at commercial and biotechnological level [7-16]. In the coming days, it is expected that probably the significance of coldactive enzymes will be more than the thermostable enzymes. The important characteristics of psychrophilic or cold-active enzymes that fascinated its scope in biotechnology are; (1) they are cost effective as less amount of enzyme is required, (2) they are able to catalyze reaction without additional thermal aid, and (3) they can be inactivated selectively by mild heat input [17]. The application of cold-active enzymes can be beneficial not only for low energy requirement and their high specific activity but also due to their informal inactivation by relatively low heat. Furthermore, during the food processing adverse chemical reactions and bacterial contamination may be reduces at low temperature [18]. Nowadays, specific catalytic activity of cold-active enzymes is under consideration of global scientific community and need to explore at industrial level. 


\section{SOURCE OF COLD-ACTIVE ENZYMES}

The literatures suggested that cold-active enzymes are found in both prokaryotes and eukaryotes. However, most of the cold-active enzymes are obtained from microorganisms and fishes living in Arctic zones [15]. Most of our planet Earth has cold regions as it is surrounded by deep oceans that always bear temperature near about $3{ }^{\circ} \mathrm{C}$ [19]. Psychrophiles are those extremophiles which are inhabitants of cold places [17]. Psychrophilic organisms are further categorized, on the basis of growth temperature, into psychrophiles and psychrotrophs/psychrotolerants. The optimum growth temperature for the psychrophiles is below $15^{\circ} \mathrm{C}$; however, for psychrotrophs it is about $20-25^{\circ} \mathrm{C}$ [20]. These organisms are located in the cold regions of the Earth including polar zones, high mountains, glaciers, and deep oceans along with exteriors of flora and fauna surviving in cold atmospheres [21-27]. Psychrophilic microorganisms, including bacteria (e.g. Pseudoalteromonas, Psychrobacter, Polaromonas, Psychroflexus, Polaribacter, and Pseudomonas), archaea (e.g. Methanogenium and Methanococcoides), yeasts (e.g. Candida and Cryptococcus), fungi (e.g. Penicillium and Cladosporium), and microalgae (e.g. Chlamydomonas and Chloromonas) are basically located in soils, waters, plants, and animals of cold regions [10-11,13,15-16]. The isolation of these microorganisms and potential applications of cold-active enzymes are already described in many published literatures $[10,13,15-16]$. These psychrophiles are able to produce cold-active enzymes, namely, amylase, cellulase, pectinase, protease, and lipase that are able to degrade starch, cellulose, pectin, protein, and lipid, respectively [8-11,13-16]. Some of the latest coldactive enzymes and its producing microorganisms are presented in Table 1 . The details of recently isolated enzymes and their mechanism are described by Santiago et al. [28].

\section{COLD-ACTIVE ENZYMES IN FOOD TECHNOLOGY}

There are tremendous scope of cold-active enzymes in food industry and biotechnology [7]. Some of the important applications are in milk, juice, meat, and baking industries. Cold-active $\beta$-galactosidase is responsible for the decreasing of lactose amount in milk processing industry. Lactose, a disaccharide sugar, is accountable for lactose intolerance throughout the world. Pectinases are used during juice extraction process in the fruit juice industry that reduces the viscosity and refine final product. In the meat processing industry, cold-active proteases are used for meat tenderization process. Some enzymes including proteases, amylases, and xylanases are helpful in baking processes to reduce the dough fermentation time along with retention of aromas and moisture levels. Other cold enzymes may also be used as substitutes to mesophilic and thermophilic enzymes in many industries [7]. Advantages of cold-adapted enzymes over mesophilic and thermophilic enzymes are described in various publications $[15,17,29,30]$. Nowadays, psychrophilic enzymes are mostly used in meat tenderization, food processing, flavoring, baking, brewing, cheese production, and in animal feed. Due to specific characteristic of cold-active enzymes, we can conclude that cold-active enzymes have much more to contribute in the field of food biotechnology. Even though the cold-active enzymes have high specific activity but small half-life and low thermal stability are the major drawback that limits utilization of such enzymes at industrial level. To increase thermal and solvent stability of cold-active enzymes, different methods of enzyme immobilization are recommended by various researchers [31]. Along with immobilization, different molecular tactics, for example, protein engineering, recombinant DNA technology and metagenomic approach could also be used to cope the commercial expectations and development of unique cold-active enzymes. Hence, instead of traditional methods of cold-active enzyme production (Fig. 1), these novel approaches could also contribute significant role in food industries.

The latest example of novel cold-active $\alpha$-amylase (AmyA1) isolated from Antarctic psychrotolerant fungus (Geomyces pannorum) and its application in baking industry is reported by He et al. [32]. The study revealed that AmyA1 would have a great potential in traditional baking and food industry. AmyA1 was also immobilized on magnetic nanoparticles to improve its stability for possible industrial

Table 1: Production of some important cold-active enzymes by psychrophilic/psychrotolerant microorganisms (published from 2005 and onwards)

\begin{tabular}{|c|c|c|}
\hline $\begin{array}{l}\text { Cold-active } \\
\text { enzymes }\end{array}$ & Source & Reference \\
\hline$\alpha$-amylase & Microbacterium foliorum GA2 & {$[40]$} \\
\hline$\alpha$-amylase & Bacillus cereus GA6 & {$[41]$} \\
\hline$\beta$-glucosidase & Exiguobacterium antarcticum B7 & {$[42]$} \\
\hline Alkaline protease & Stenotrophomonas maltophilia & {$[43]$} \\
\hline Chitinase & Bacillus cereus GA6 & {$[44]$} \\
\hline Esterase & Pseudomonas mandelii & {$[45]$} \\
\hline Esterase & Monascus ruber M7 & {$[46]$} \\
\hline Esterase & Psychrobacter pacificensis & {$[47]$} \\
\hline Esterase & Streptomyces coelicolor A3 & {$[48]$} \\
\hline Lipase & Pseudomonas sp. & {$[49]$} \\
\hline Lipase & Pseudomonas sp. TK-3 & {$[50]$} \\
\hline Metalloprotease & Curtobacterium luteum & {$[39]$} \\
\hline Protease & Pseudoalteromonas haloplanktis & {$[51]$} \\
\hline Protease & Pseudoalteromonas sp. & {$[52]$} \\
\hline Protease & Aspergillus ustus & {$[53]$} \\
\hline Protease & Clostridium sp. & {$[54]$} \\
\hline Protease & Pedobacter cryoconitis & {$[55]$} \\
\hline Protease & Bacillus cereus & {$[56]$} \\
\hline Protease & Chryseobacterium sp. & {$[33]$} \\
\hline Pullulanase & Exiguobacterium sp. SH3 & {$[57]$} \\
\hline Transglutaminase & Euphausia superba & {$[58]$} \\
\hline
\end{tabular}

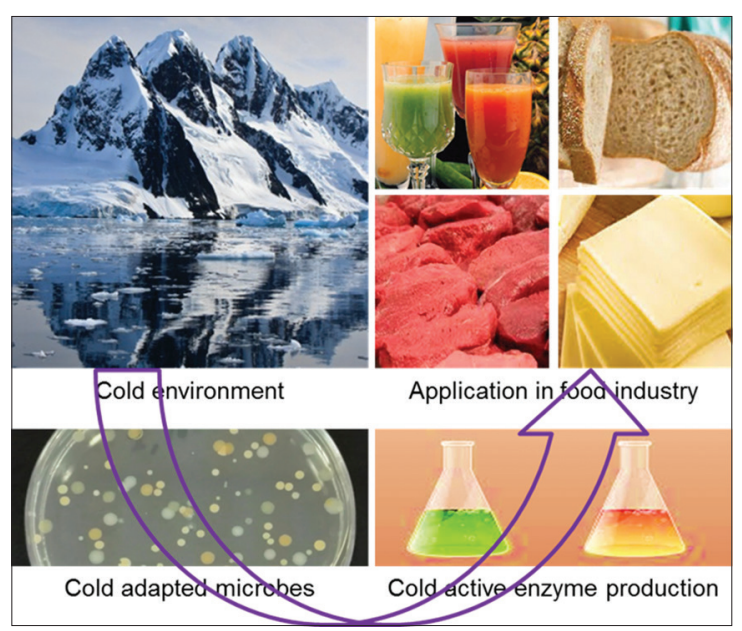

Fig. 1: Outline of cold-active enzyme production and applications 
applications [32]. In another study, production of the cold-active protease was reported from a novel Chryseobacterium sp. Along with low-temperature activity; this protease was tolerant to several organic solvents and surfactants. Furthermore, it increases meat tenderization process that could be used in food processing industry at low temperature [33]. Cold-active esterase obtained from the marine Arctic metagenomics libraries showed high activity under the influence of high salt concentrations. Due to salt tolerance property at low temperature, this esterase could be a highly valuable candidate for cheese ripening processes [34]. Lipases, another important enzyme in food processing, are isolated by many psychrophilic microbes [35]. Recently, the gene encoding lipase was isolated from Aeromicrobium sp. and cloned using Escherichia coli. The recombinant lipase showed high catalytic activity and stability at low temperatures that have potential value in industrial applications as well as in food additive [36]. Pectin, a complex heteropolysaccharide, is one of the main constituents of higher plant cells that creates complications during the extraction and clarification of fruit juice. Polygalacturonase, a pectin-degrading enzyme, is commonly used for the treatment of pectin compounds in fruit processing industries [37]. Ramya and Pulicherla [38] recommended applications of cold-active polygalacturonase from Pseudoalteromonas haloplanktis in various food industries. On the basis of in silico analysis, they proposed that cold active polygalacturonase would be a better choice in comparison to its meso and thermo counterparts [38]. Some of the important coldactive enzyme and their applications are summarized in Table 2.

Table 2: Some of the cold-active enzymes produced by psychrophilic/psychrotolerant microorganisms and their applications in food industry (published from 2005 and onwards)

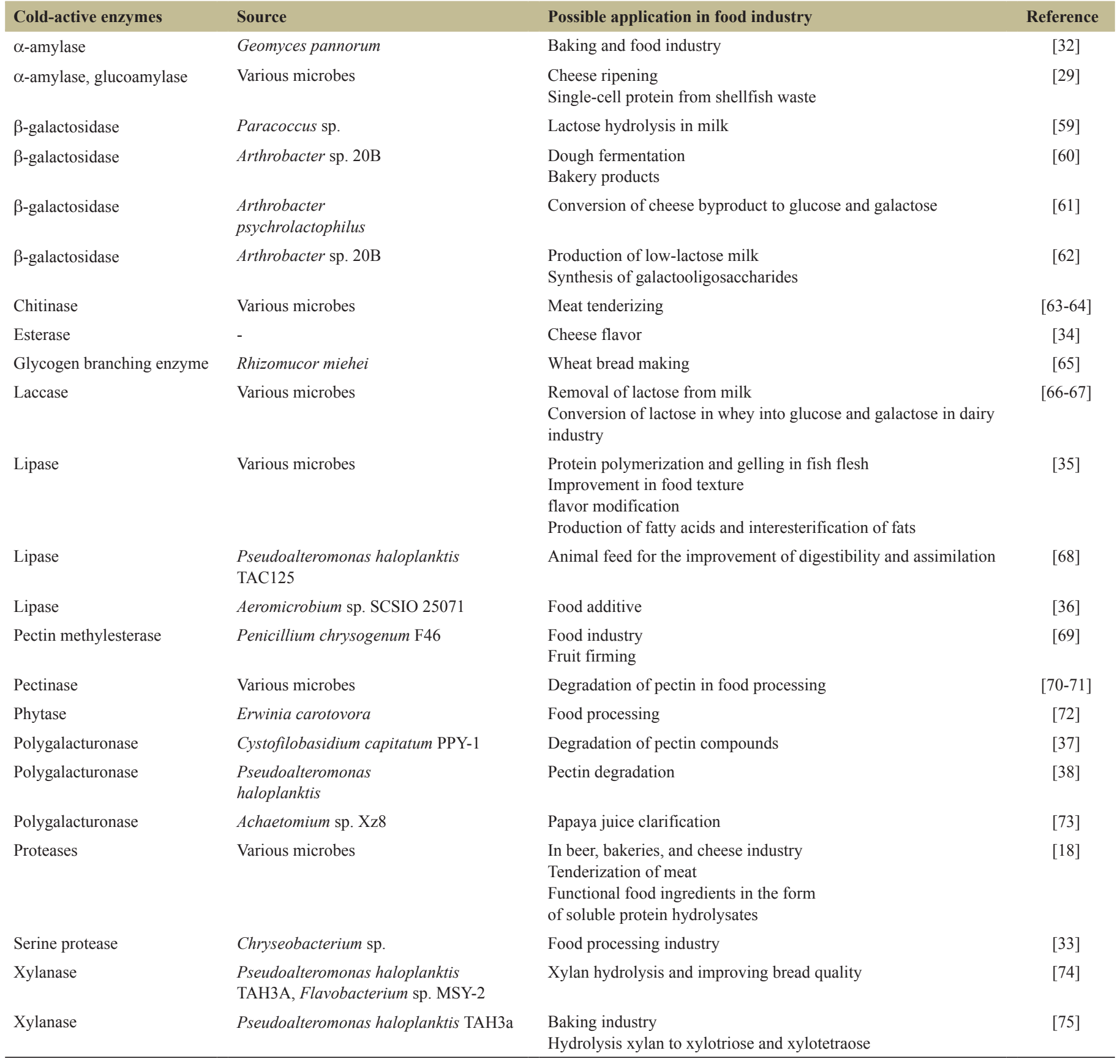




\section{FUTURE PROSPECTS}

It is well documented that most of the cold-active enzymes reported till date have high catalytic capability at low and moderate temperatures in comparison to their homologous mesophilic enzymes. This specific property of cold-active enzymes make them valuable in industry and research due to their less requirements, reduced process times, save energy costs, easy inactivation by mild heat, and the loss of volatile compounds $[18,39]$. However, in the field of food biotechnology, it needed extra effort to cope various bottlenecks specifically high cost of enzyme isolation and purification, low stability of most cold-active enzymes and least explored cold-adapted microbes from the cold habitats. Application of recombinant DNA technology, in the expression of specific genes and production of greater amount of recombinant enzymes, may be an essential and effective tool to achieve commercial requirement of the cold-active enzymes. It can be concluded that cold-active enzymes have much more to contribute in the field of food industry due to its high specific activity at low temperature. More studies are required to screen psychrophilic microbial strains from various cold habitats and apply r-DNA technology along with protein engineering to upgrade their biotechnological potential and cope commercial expectations of cold-active enzymes in food biotechnology. In this review, only specific examples of cold-active enzymes along with their potential applications in the food industry are discussed in Table 2. There is rife literature on cold-active enzymes and their applications in food and other industries. However, very few psychrophilic enzymes are used in real industrial applications, especially in food processing. Further, it is expected that these enzymes, along with their producing microorganisms, will be an asset to various industries in the near future.

\section{REFERENCES}

1. Kirk O, Borchert TV, Fuglsang CC. Industrial enzyme applications. Curr Opin Biotechnol 2002;13:345-51.

2. Wong DW. Food Enzymes-Structure and Mechanism. USA: Chapman and Hall; 1995.

3. Guomundsdottir A, Bjarnason J. Applications of cold-adapted proteases in the food industry. In: Rastall R, editor. Novel Enzyme Technology for Food Applications. Cambridge, UK: Woodhead Publishing; 2007. p. 205-14.

4. Oort M. Enzymes in food technology-introduction. In: Robert JW, Oort M, editor. Enzymes in Food Technology. Oxford: WileyBlackwell; 2009. p. 1-16.

5. Avendano KA, Anguiano M, Lopez CE, Montanez LE, Sifuentes L, Balagurusamy N. Microbial enzymes applications in food processing. Agro Food Ind Hi Tech 2016;27:63-7.

6. Singh R, Kumar M, Mittal A, Mehta PK. Microbial enzymes: Industrial progress in $21^{\text {st }}$ century 3 Biotech 2016;6:174.

7. Gerday C, Aittaleb M, Bentahir M, Chessa JP, Claverie P, Collins T, et al. Cold-adapted enzymes: From fundamentals to biotechnology. Trends Biotechnol 2000;18:103-7.

8. Demirjian DC, Morís-Varas F, Cassidy CS. Enzymes from extremophiles. Curr Opin Chem Biol 2001;5:144-51.

9. Eichler J. Biotechnological uses of archaeal extremozymes. Biotechnol Adv 2001;19:261-78.

10. Cavicchioli R, Siddiqui KS, Andrews D, Sowers KR. Lowtemperature extremophiles and their applications. Curr Opin Biotechnol 2002;13:253-61.

11. Deming JW. Psychrophiles and polar regions. Curr Opin Microbiol 2002;5:301-9.
12. Gupta R, Beg QK, Lorenz P. Bacterial alkaline proteases: Molecular approaches and industrial applications. Appl Microbiol Biotechnol 2002;59:15-32.

13. Margesin R, Feller G, Gerday C, Russell N. Cold-adapted microorganisms: Adaptation strategies and biotechnological potential. In: Bitton G, editor. The Encyclopedia of Environmental Microbiology. Vol. 2. New York: John Wiley \& Sons; 2002. p. 871-85.

14. van den Burg B. Extremophiles as a source for novel enzymes. Curr Opin Microbiol 2003;6:213-8.

15. Feller G, Gerday C. Psychrophilic enzymes: Hot topics in cold adaptation. Nat Rev Microbiol 2003;1:200-8.

16. Georlette D, Blaise V, Collins T, D’Amico S, Gratia E, Hoyoux A, et al. Some like it cold: Biocatalysis at low temperatures. FEMS Microbiol Rev 2004;28:25-42.

17. Javed A, Qazi JI. Psychrophilic microbial enzymes implications in coming biotechnological processes. Am Sci Res J Eng Technol Sci 2016;23:103-20.

18. Kuddus M, Ramteke PW. Recent developments in production and biotechnological applications of cold-active microbial proteases. Crit Rev Microbiol 2012;38:330-8.

19. Austin B. Marine Microbiology. Cambridge: Cambridge University Press; 1988.

20. Morita RY. Psychrophilic bacteria. Bacteriol Rev 1975;39:144-67.

21. Willerslev E, Hansen AJ, Poinar HN. Isolation of nucleic acids and cultures from fossil ice and permafrost. Trends Ecol Evol 2004;19:141-7.

22. Hodson A, Anesio AM, Tranter M, Fountain A, Osborn M, Priscu J, et al. Glacial ecosystems. Ecol Monogr 2008;78:41-67.

23. MacDonell S, Fitzsimons S. The formation and hydrological significance of cryoconite holes. Prog Phys Geogr 2008;32:595-610.

24. Pulicherla KK, Ghosh M, Kumar PS, Rao KR. Psychrozymes-the next generation industrial enzymes. J Marine Sci Res Dev 2011;1:102.

25. Buzzini P, Branda E, Goretti M, Turchetti B. Psychrophilic yeasts from worldwide glacial habitats: Diversity, adaptation strategies and biotechnological potential. FEMS Microbiol Ecol 2012;82:217-41.

26. Loperena L, Soria V, Varela H, Lupo S, Bergalli A, Guigou M, et al. Extracellular enzymes produced by microorganisms isolated from maritime Antarctica. World J Microbiol Biotechnol 2012;28:2249-56.

27. Struvay C, Feller G. Optimization to low temperature activity in psychrophilic enzymes. Int J Mol Sci 2012;13:11643-65.

28. Santiago M, Ramírez-Sarmiento CA, Zamora RA, Parra LP. Discovery, molecular mechanisms, and industrial applications of cold-active enzymes. Front Microbiol 2016;7:1408.

29. Kuddus M, Roohi, Arif JM, Ramteke PW. An overview of cold-active microbial $\alpha$-amylase: Adaptation strategies and biotechnological potentials. Biotechnol 2011;10:246-58.

30. Kuddus M. Cold-active microbial enzymes. Biochem Physiol 2015;4:E132.

31. Lee CW, Jang SH, Chung HS. Improving the stability of cold-adapted enzymes by immobilization. Catalysts 2017;7:112.

32. He L, Mao Y, Zhang L, Wang H, Alias SA, Gao B, et al. Functional expression of a novel $\alpha$-amylase from Antarctic psychrotolerant fungus for baking industry and its magnetic immobilization. BMC Biotechnol 2017;17:22.

33. Mageswari A, Subramanian P, Chandrasekaran S, Karthikeyan S, Gothandam KM. Systematic functional analysis and application of a cold-active serine protease from a novel Chryseobacterium sp. Food Chem 2017;217:18-27.

34. De Santi C, Altermark B, Pierechod MM, Ambrosino L, de Pascale D, Willassen NP, et al. Characterization of a cold-active and salt tolerant esterase identified by functional screening of arctic metagenomic libraries. BMC Biochem 2016;17:1. 
35. Joseph B, Ramteke PW, Thomas G, Shrivastava N. Standard review on cold-active microbial lipases: A versatile tool for industrial applications. Biotechnol Mol Biol Rev 2007;2:39-48.

36. Su H, Mai Z, Yang J, Xiao Y, Tian X, Zhang S, et al. Cloning, expression, and characterization of a cold-active and organic solventtolerant lipase from Aeromicrobium sp. SCSIO 25071. J Microbiol Biotechnol 2016;26:1067-76.

37. Nakagawa T, Nagaoka T, Miyaji T, Tomizuka N. Cold-active Polygalacturonase from psychrophilic-basidiomycetous yeast Cystofilobasidium capitatum strain PPY-1. Biosci Biotechnol Biochem 2005;69:419-21.

38. Ramya LN, Pulicherla KK. Molecular insights into cold active polygalacturonase enzyme for its potential application in food processing. J Food Sci Technol 2015;52:5484-96.

39. Kuddus M, Ramteke PW. A cold-active extracellular metalloprotease from Curtobacterium luteum (MTCC 7529): Enzyme production and characterization. J Gen Appl Microbiol 2008;54:385-92.

40. Roohi, Kuddus M. Bio-statistical approach for optimization of coldactive $\alpha$-amylase production by psychrotolerant Microbacterium foliorum GA2 in solid state fermentation. Biocatal Agric Biotech 2014;3:175-81.

41. Roohi R, Kuddus M, Saima S. Cold-active detergent-stable extracellular $\alpha$-amylase from Bacillus cereus GA6: Biochemical characteristics and its perspectives in laundry detergent formulation. J Biochem Tech 2013;4:636-44.

42. Zanphorlin LM, de Giuseppe PO, Honorato RV, Tonoli CC, Fattori J, Crespim E, et al. Oligomerization as a strategy for cold adaptation: Structure and dynamics of the GH1 beta-glucosidase from Exiguobacterium antarcticum B7. Sci Rep 2016;6:23776.

43. Kuddus M, Ramteke PW. Production optimization of an extracellular cold-active alkaline protease from Stenotrophomonas maltophilia MTCC 7528 and its application in detergent industry. Afr J Microbiol Res 2011;5:809-16.

44. Roohi R, Kuddus M. Statistical optimization of cold-active chitinase production by mutagenized cells of multi-enzyme producing Bacillus cereus GA6. Rend Lincei 2015;26:271-80.

45. Truongvan N, Jang SH, Lee C. Flexibility and stability trade-off in active site of cold-adapted pseudomonas Mandelii esterase estK. Biochemistry 2016;55:3542-9.

46. Guo H, Zhang Y, Shao Y, Chen W, Chen F, Li M, et al. Cloning, expression and characterization of a novel cold-active and organic solvent-tolerant esterase from Monascus ruber M7. Extremophiles 2016;20:451-9.

47. Wu G, Zhang X, Wei L, Wu G, Kumar A, Mao T, et al. A coldadapted, solvent and salt tolerant esterase from marine bacterium Psychrobacter pacificensis. Int J Biol Macromol 2015;81:180-7.

48. Brault G, Shareck F, Hurtubise Y, Lepine F, Doucet N. Isolation and characterization of Est C, a new cold-active esterase from $S$. Coelicolor A3(2). PLoS One. 2012;7:e32041.

49. Ganasen M, Yaacob N, Rahman RN, Leow AT, Basri M, Salleh AB, et al. Cold-adapted organic solvent tolerant alkalophilic family I.3 lipase from an Antarctic pseudomonas. Int J Biol Macromol 2016;92:1266-76.

50. Tanaka D, Yoneda S, Yamashiro Y, Sakatoku A, Kayashima T, Yamakawa K. Characterization of a new cold-adapted lipase from Pseudomonas sp. TK-3. Appl Biochem Biotechnol 2012;168: 327-38.

51. Pascale D,S Giuliani M, De Santi C, Bergamasco N, Amoresano A, Carpentieri A, et al. PhAP protease from Pseudoalteromonas haloplanktis TAC125: Gene cloning, recombinant production in E. Coli and enzyme characterization. Polar Sci 2010;4:285-94.

52. Wang Q, Hou Y, Xu Z, Miao J, Li G. Purification and properties of an extracellular cold-active protease from the psychrophilic bacterium Pseudoalteromonas sp. NJ276. Biochem Eng 2008;38:362-8.
53. Damare S, Raghukumar C, Muraleedharan U, Raghukumar S. Deepsea fungi as a source of alkaline and cold-tolerant proteases. Enzyme Microb Technol 2006;39:172-81.

54. Alam SI, Dube S, Reddy GS, Bhattacharya BK, Shivaji S, Singh L. Purification and characterization of extracellular protease produced by Clostridium sp. From Schirmacher oasis, Antarctica. Enzyme Microb Technol 2005;36:824-31.

55. Margesin R, Dieplinger H, Hofmann J, Sarg B, Lindner H. A coldactive extracellular metalloprotease from Pedobacter cryoconitisproduction and properties. Res Microbiol 2005;156:499-505.

56. Shi JS, Wu QF, Xu ZH, Tao WY. Identification of psychrotrophs SYP-A2-3 producing cold-adapted protease from the no 1 Glacier of china and study on its fermentation conditions. Wei Sheng Wu Xue Bao 2005;45:258-63.

57. Rajaei S, Noghabi KA, Sadeghizadeh M, Zahiri HS. Characterization of a $\mathrm{pH}$ and detergent-tolerant, cold-adapted type I pullulanase from Exiguobacterium sp. SH3. Extremophiles 2015;19:1145-55.

58. Zhang Y, He S, Simpson BK. A cold active transglutaminase from antarctic krill (Euphausia superba): Purification, characterization and application in the modification of cold-set gelatin gel. Food Chem 2017;232:155-62.

59. Wierzbicka-Wos A, Cieslinski H, Wanarska M, Kozlowska-Tylingo $\mathrm{K}$, Hildebrandt P, Kur J. A novel cold-active b-D-galactosidase from the Paracoccus sp. 32d - gene cloning, purification and characterization. Microb Cell Fact 2011;10:108-20.

60. Białkowska AM, Cieśliński H, Nowakowska KM, Kur J, Turkiewicz M. A new $\beta$-galactosidase with a low temperature optimum isolated from the Antarctic Arthrobacter sp. 20B: Gene cloning, purification and characterization. Arch Microbiol 2009; 191:825.

61. Nam ES, Kim YH, Shon KH, Ahn JK. Isolation and characterization of a psychrophilic bacterium producing cold active lactose hydrolyzing enzyme from soil of Mt. Himalaya in Nepal. African J Microbiol Res 2011;5:2198-206.

62. Pawlak-Szukalska A, Wanarska M, Popinigis AT, Kur J. A novel cold-active $\beta$-galactosidase with transglycosylation activity from the Antarctic Arthrobacter sp. 20B Gene cloning, purification and characterization. Process Biochem 2014;49:2122-33.

63. Dahiya N, Tewari R, Hoondal GS. Biotechnological aspects of chitinolytic enzymes: A review. Appl Microbiol Biotechnol 2006;71:773-82.

64. Cavicchioli R, Charlton T, Ertan H, Mohd Omar S, Siddiqui KS, Williams TJ, et al. Biotechnological uses of enzymes from psychrophiles. Microb Biotechnol 2011;4:449-60.

65. Wu S, Liu Y, Yan Q, Jiang Z. Gene cloning, functional expression and characterisation of a novel glycogen branching enzyme from Rhizomucor miehei and its application in wheat breadmaking. Food Chem 2014;159:85-94.

66. Kunamneni A, Plou FJ, Ballesteros A, Alcalde M. Laccases and their applications: A patent review. Recent Pat Biotechnol 2008;2:10-24.

67. Joseph B, Ramteke PW, Thomas G. Cold active microbial lipases: Some hot issues and recent developments. Biotechnol Adv 2008;26:457-70.

68. Tutino ML, di Prisco G, Marino G, de Pascale D. Cold-adapted esterases and lipases: From fundamentals to application. Protein Pept Lett 2009;16:1172-80.

69. Pan X, Tu T, Wang L, Luo H, Ma R, Shi P. A novel low-temperatureactive pectin methylesterase from Penicillium chrysogenum $\mathrm{F} 46$ with high efficiency in fruit firming. Food Chem 2014;162:229-34.

70. Adapa V, Ramya LN, Pulicherla KK, Rao KR. Cold active pectinases: Advancing the food industry to the next generation. Appl Biochem Biotechnol 2014;172:2324-37.

71. Martin MC, Morata de Ambrosini VI. Cold-active acid pectinolytic system from psychrotolerant Bacillus: Color extraction from red grape skin. Am J Enol Vitic 2013;64:495-504. 
Kuddus.: Application of cold-active enzymes in food industry 2018;6(3):58-63

72. Huang H, Luo H, Wang Y, Fu D, Shao N, Yang P, et al. Novel lowtemperature-active phytase from Erwinia carotovora var. carotovota ACCC 10276. J Microbiol Biotechnol 2009;19:1085-91.

73. Tu T, Meng K, Bai Y, Shi P, Luo H, Wang Y, et al. High-yield production of a low-temperature-active polygalacturonase for papaya juice clarification. Food Chem 2013;141:2974-81.

74. Dornez E, Verjans P, Arnaut F, Delcour JA, Courtin CM. Use of psychrophilic xylanases provides insight into the xylanase functionality in bread making. J Agric Food Chem 2011;59:9553-62.
75. Collins T, Gerday C, Feller G. Xylanases, xylanase families and xtremophilic xylanases. FEMS Microbiol Rev 2005;29:3-23.

How to cite this article:

Kuddus M. Cold-active enzymes in food biotechnology: An updated mini review. J App Biol Biotech. 2018;6(3):58-63.

DOI: $10.7324 / J A B B .2018 .60310$ 